\title{
Investigation of Petroleum Source Rock Potential and Maturity in Pologbene-001 from resistivity and density logs, Northern Depobelt Eocene Deposits, Niger Delta, Nigeria
}

\author{
Benson Akinbode Olisa (Ph.D) \\ Department of Applied Geophysics \\ The Federal University of Technology, Akure, Nigeria. \\ (Akinbode7@yahoo.com) \\ DOI: $10.31364 /$ SCIRJ/v6.i8.2018.P0818554 \\ http://dx.doi.org/10.31364/SCIRJ/v6.i8.2018.P0818554
}

\begin{abstract}
Petroleum source rock potential and maturity of Pologbene-001 in the Northern depobelt was investigated using Rock-Eval, resistivity and bulk density data. The Rock-Eval data was used to select Eocene age. TOC was calculated from gamma ray (GR) curve to determine the TOC variation in shale sections. The source rock potential was further investigated using the density and resistivity data. These studies were done to resolve the controversies generated regarding the origin of petroleum source rock in the Niger Delta. Results showed that ten shale sections were considered good for source rock analysis based on their thicknesses, greater than 30ft (100m). GR (TOC) calculated from GR curve indicated that TOC decreases with depth. Agbada sections (shallower formation) has GR (TOC) that ranges from 3.7 to $4.4 \mathrm{wt} \%$, while Akata sections (deeper formation) has GR (TOC) averages 3.8 and 3.9 wt \%. Trends of the bulk density and resistivity data were unable to detect the source rock directly in Agbada sections, but resistivity variation with depth was confirmatory. Akata sections were easily identified with opposite trends of resistivity and bulk density curves together with clear maturity zones. Investigations showed three zones of organic maturity of source rocks: an immature zone above, a peak generation and accumulation zone in the middle and a mature, expulsion and migration zone at the base. True resistivity (Rt) is low in the immature zone, increase to maximum in the accumulation zone, and deceases to an intermediate value in the migration zone.
\end{abstract}

Key words: Source rock, resistivity, density, depobelt, maturity

\section{INTRODUCTION}

Petroleum source rock of the Niger Delta has been a subject of controversy. The Niger Delta Basin, Fig. 1, located on the western edge of the African continent and southern part of Nigeria, covers an area of $75,000 \mathrm{~km}^{2}$ and consists of 9000 12,000 m of clastic sediments (Oluwajana et al. 2017).

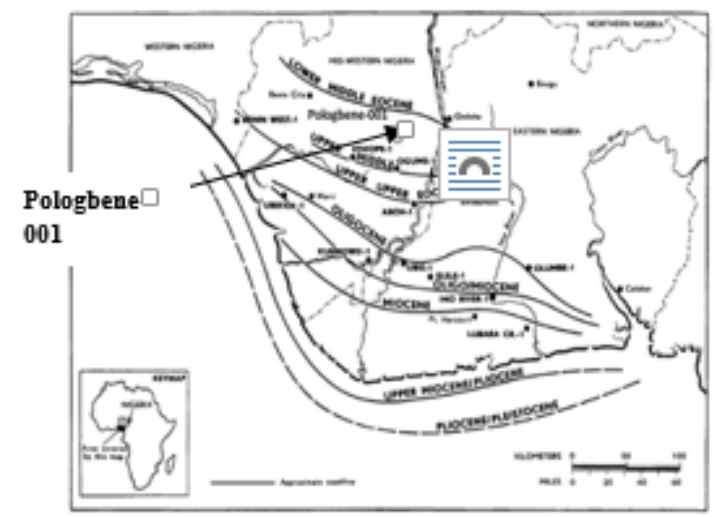

Figure 1: Location of Pologbene-001 and paleogeography of the Tertiary Niger Delta (Oluwajana et al. 2017)
Following a major marine transgression in the Paleocene, the paleo-Niger Delta started to prograde to the southwest into the equatorial Atlantic Ocean (Ekweozor and Daukoru, 1994). This sediment build-up was accompanied by growth fault tectonics normal to the direction of progradation which resulted in a series of seven parallel fault-bounded depositional belts (depobelts) namely: Northern Delta, Ughelli, Central Swamp I, Central Swamp II, Coastal Swamp I, Coastal Swamp II and Offshore depobelt. These depobelts are successively younger from north to south. The studied well (Pologbene-001) lies in the Northern depobelt considered the oldest and as one of the productive hydrocarbon depobelt in the Niger Delta Basin. There are three lithostratigraphic units recognized in the Niger Delta namely Akata, Agbada and Benin Formations (Nyantakyi et al. 2014). The Agbada Formation has intervals that contain organic-carbon contents sufficient to be considered good source rocks (Ekweozor and Okoye 1980). The intervals, however, rarely reached thickness sufficient to produce a world-class oil province and are immature in various parts of the delta (Evamy et al. 1978). The Akata shale is present in large volumes beneath the Agbada Formation and is at least volumentrically sufficient to generate enough oil for a world class oil province such as the 
Niger Delta. Based on organic-matter content and type, Evamy et al. (1978) proposed that both the marine shale (Akata Formation) and the shale interbedded with paralic sandstone (lower Agbada Formation) were the source rocks for the Niger Delta oils.

The controversies generated could be as a result of insufficient sample data used in the analyses coupled with sample transportation from the field to the laboratories leading to sediments boycott, Meyer and Nederlof (1984). The most complete and readily available well data are the wireline logs which give continuous sampling of data and log responses have effects on source rock potential investigation.

\section{GEOLOGICAL SETTINGS}

The Niger Delta, situated in the Gulf of Guinea at the southern end of the Cretaceous Benue trough rift basin, represents one of the largest modern deltas and most productive regions for petroleum exploration in the world (Benesh et al. 2014).

All available gravity and magnetic data for the Niger Delta Basin and adjacent areas offshore were merged and analyzed for the purpose of mapping basement structures (Haack et al., 2000). Strong northeast to southwest trends dominate the magnetic signal across the delta. These trends are parallel to fracture zone patterns in the deep ocean and are believed to have formed during the opening of the Mid-Atlantic Ocean in the Late Jurassic-Early Cretaceous time.

The Niger Delta consists of a series of tear faults that occur near the northern termination of the outer fold-and-thrust belt of the Niger Delta. The outer fold-and-thrust belt represents the more distal of the two fold-and-thrust belts that accommodate outboard shortening driven by gravitational collapse and extension of the deltaic sequence on the continental shelf. For most of the outer fold-and thrust belt, the primary detachment lies within the Akata Formation (Corredor et al., 2005), a time transgressive, thick marine shale that generally sits atop an Upper Cretaceous sedimentary sequence, which itself overlies an Early Cretaceous oceanic crust (Wu and Bally, 2000). This shale is believed to be one of the major source rocks for hydrocarbons in the delta and also contains some locally developed turbidite sands. Additionally, the formation generally exhibits a low seismic velocity that reflects fluid overpressures that locally reach $90 \%$ of the lithostatic stress (Bilotti et al., 2005, Bouvier 1989). Above the Akata Formation lies the Agbada Formation. This formation is Eocene to Pleistocene in age and is believed to be the dominant petroleum-bearing unit in the delta.

Published reports on geochemical studies on petroleum source rocks have suggested major source rocks were shales of Agbada Formation (Short and Stauble 1967, Bustin 1988). This view was supported by Hedberg (1968) who stated that the high wax content of the oil reflects terrestrial organic sources and thus an Agbada source. However, Weber and Daukoru 1975 proposed a deep Akata Formation hydrocarbon source and migration routes that included growth faults. Evamy et al. (1978) based on maturation studies concluded that the Akata Formation is the main source rock in the eastern part of the delta. In the western part, where the Agbada
Formation is more deeply buried, the Agbada provided a significant source.

\section{Pologbene-001 Sequence}

Short and Stauble (1967) gave the stratigraphic positions of the three formations in descending order (Benin, Agbada and Akata Formations) in their type localities. The respective depth intervals are $0-4,600 \mathrm{ft}(0-1402 \mathrm{~m})$ at Alele-1, 5,7609500ft (1756-2895m) at Agbada-2 and 7,180-11,121(2188$3390 \mathrm{~m})$ at Akata-2.

Ekweozor and Daukoru, (1994) in examining a cross section of wells indicated that Akata formation was penetrated in the northern depobelt. They placed the top of Akata and Agbada Formations at about $1700 \mathrm{~m}(5577 \mathrm{ft})$ and $700 \mathrm{~m}(2277 \mathrm{ft})$.

\section{SOURCE ROCK RESPONSES OF RESISTIVITY AND DENSITY LOG}

The organic content of a formation has varying effects on resistivity and density logs. In evaluating these effects, organic-rich rocks are assumed to be composed of three components, the rock matrix, the solid organic matter, and the fluid(s) filling the pore space (Passey et al. 1990). Non-source rocks are composed of only two components: the matrix and fluid filling the pore space. In immature source rocks, solid organic matter and rock matrix comprise the solid fraction, and formation water fills the pore space. As the source rock matures, a portion of the organic matter is transformed to liquid (or gaseous) hydrocarbons which move into the pore space, displacing the formation water, (Passey et al., 1990; Meyer and Nederlof 1984).

Sediments can be regarded as consisting of heavy and light fractions (Meyer and Nederlof, 1984). The heavy fraction is the mineral matter, and the light fraction is the formation fluids. In source rocks, the contained organic matter is also part of the light fraction. During compaction, water is expelled; consequently, the density increases. Because of the presence of organic material, source rocks retain a greater amount of the light fraction than organic-lean sediments, and thus appear on density logs to be somewhat less compacted, Fig. 2. Organic matter, like the mineral matrix, is normally not electrically conductive. Organic-rich sediments, therefore, have a higher resistivity than organic-lean sediments. 


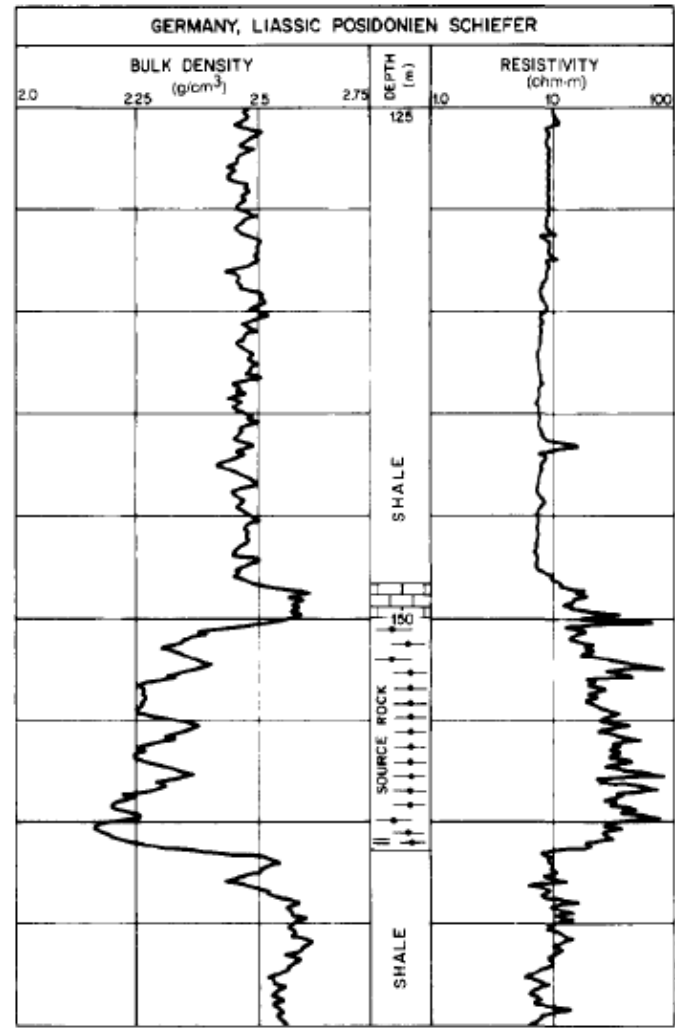

Figure 2: Meyer and Nederlof (1984)

\section{SOURCE ROCK AND MATURITY}

The log most useful for the identification of maturity zones are the resistivity and density-neutron log, Hinds and Berg, (1990), Fig. 3. The resistivity response is shown by values of log readings averaged over the cored intervals.

True resistivity $\left(R_{t}\right)$ is low in the immature zone (Hinds and Berg, 1990), and decreases to intermediate values in the mature zone (Fig. 3A). Density - porosity and neutronporosity values show a separation of in the immature zone, whereas the values are nearly equal in the accumulation and mature zones (Fig. 3B).

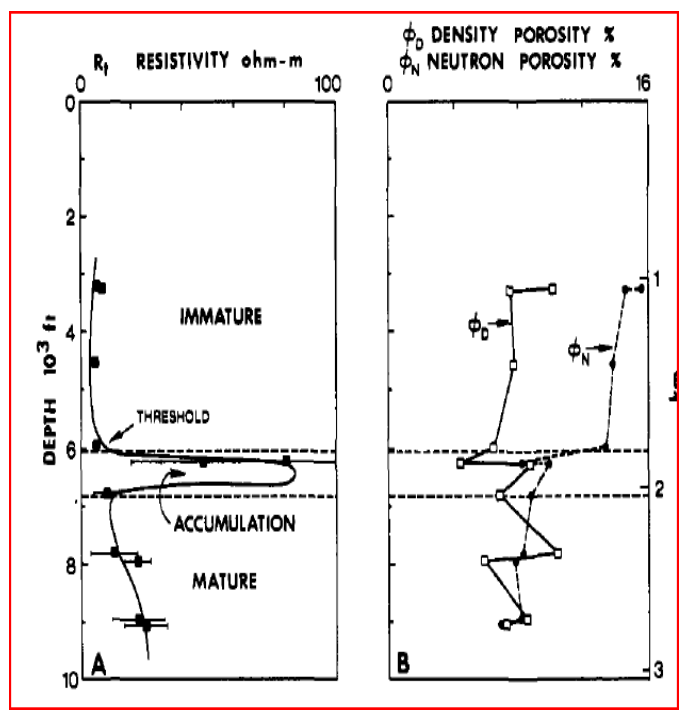

Figure 3: Well log response as a function of depth (Hinds and Berg, 1990).

Hydrocarbons are generated in the accumulation zone but remain trapped in the pore of the rock matrix. Hydrocarbons have been generated at the maturity zone but expelled from the rock matrix to adjacent fractures. Thus the mature zone represents the level of potential oil production. The immature zone contains less hydrocarbons.

\section{MATERIALS AND METHODS}

Rock-Eval pyrolysis data of thirteen samples together with resistivity and bulk density data, from Pologbene-001 (Table 1), Eocene section selected for the analysis was obtained from SPDC (Shell Petroleum and Development Company, PortHarcourt, Nigeria), from Pologbene-001 were used to determine the source rock potential and maturity levels of the Eocene source intervals of well. The well was drilled on the northern depobelt and the data available for this study were: gamma ray, density, sonic and resistivity logs. In analyzing the source rock potential, the studied well reservoir interval was removed using GR log curves (Passey et al. 1990). The shale intervals were serialized (Table 2). Source rock quality is a function of the amount and type of organic matter in the rock. The boundary between a fair and a poor clastic source rock is commonly defined at approximately 0.5 percent total organic carbon content (Tissot and Welte, 1978). Good clastic source rocks generally contain greater than 1.0 percent TOC. Organic-rich shale is present when there is an increase in resistivity and a decrease in bulk density.

Table 1: Borehole data at Pologbene-001 


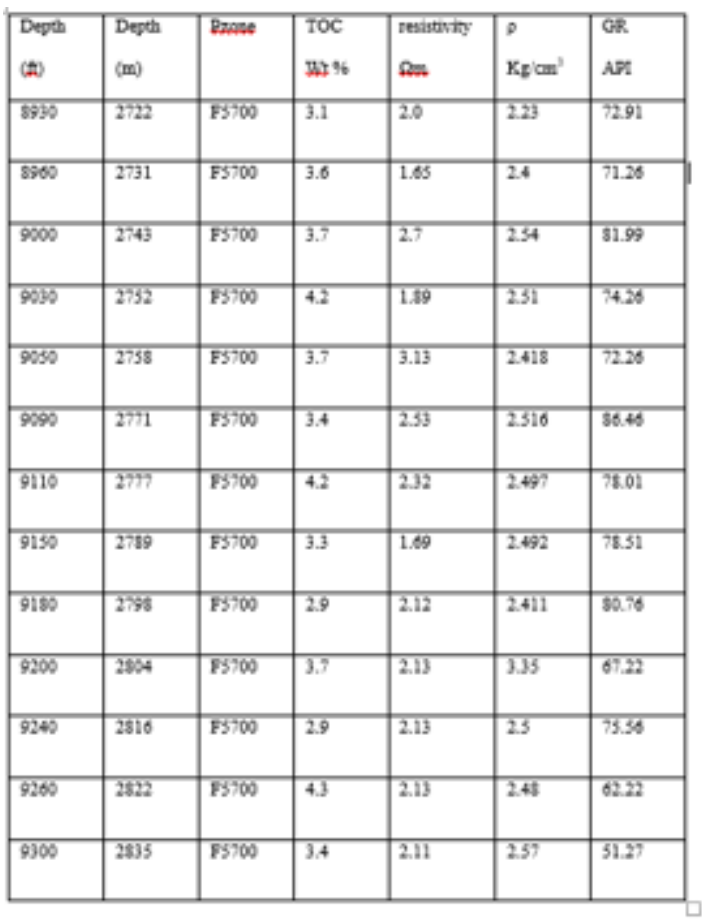

Table 2: Electric logs of shale Intervals studied (Pologbene001)

\begin{tabular}{|l|l|l|l|l|l|l|l|l|}
\hline s/n & $\begin{array}{l}\text { Shale } \\
\text { lithology } \\
\text { in } \\
\text { descending } \\
\text { order }\end{array}$ & $\begin{array}{l}\text { Shale } \\
\text { thichness } \\
\text { (At) }\end{array}$ & $\begin{array}{l}\text { Shale } \\
\text { thickness } \\
(\mathrm{m})\end{array}$ & $\begin{array}{l}\text { Depth } \\
\text { range(t) }\end{array}$ & $\begin{array}{l}\text { Depth } \\
\text { range(m) }\end{array}$ & $\begin{array}{l}\text { Av. } \\
\text { GR(TOC) } \\
\text { ut\%\% }\end{array}$ & $\begin{array}{l}\text { Av. } \\
\text { Res. } \\
\text { Sm }\end{array}$ & $\begin{array}{l}\text { Av. } \\
\text { Bulk } \\
\text { dens. } \\
\text { (kg m3) }\end{array}$ \\
\hline 1 & 21 & 416 & 127 & $2119-2535$ & $646-773$ & 4.4 & - & 2.2 \\
\hline 2 & 24 & 195 & 59 & $2565-2760$ & $782-841$ & 4.3 & - & 2.1 \\
\hline 3 & 30 & 197 & 60 & $2818-3016$ & $858-919$ & 4.2 & - & 2.2 \\
\hline 4 & 35 & 128 & 39 & $3102-3230$ & $945-984$ & 4.0 & - & 2.2 \\
\hline 5 & 37 & 282 & 85 & $3318-3600$ & $1011-1097$ & 4.2 & - & 2.3 \\
\hline 6 & 39 & 248 & 75 & $3805-4053$ & $1060-1235$ & 3.9 & 3.7 & 2.3 \\
\hline 7 & 40 & 96 & 29 & $4088-4184$ & $1246-1275$ & 3.8 & 3.4 & 2.3 \\
\hline 8 & 41 & 132 & 40 & $4224-4356$ & $1287-1328$ & 3.7 & 3.8 & 2.3 \\
\hline 9 & 159 & 120 & 37 & $8057-8177$ & $2456-2492$ & 3.9 & 3.1 & 2.5 \\
\hline 10 & 189 & 118 & 36 & $8935-9053$ & $2723-2759$ & 3.8 & 2.2 & 2.5 \\
\hline
\end{tabular}

A model equation was developed to calculate TOC from GR $\log$ (Olisa 2016, Olisa et al.2018):

$Y=29.6 x-31.7$,

where $\mathrm{y}$ is GR value of organic-rich shale at depth and $\mathrm{x}$ is TOC.

The calculated TOC, resistivity and density values (obtained directly from the logs) were plotted against depth to determine the variations of the parameters. Geochemical and core measurements have shown three zones of organic maturity for source rock materials: an immature zone above, a peak generation and accumulation zone in the middle and a mature, expulsion and migration zone, at the base. True resistivity $\left(\mathrm{R}_{\mathrm{t}}\right)$ is low in the immature zone, increase to maximum in the accumulation zone, and deceases to an intermediate value in the migration zone.

\section{Eocene section \\ VI. RESULTS AND DISCUSSION}

Eocene section (core data) is at $8930-9330 \mathrm{ft}(2722-2835 \mathrm{~m})$ (Table 1). Based on GR analysis, there are 215 shales ranging from Ift to $416 \mathrm{ft}$ ( $0.3 \mathrm{~m}$ to $127 \mathrm{~m})$ in the interval. The selected shales of exploration standard (greater than $100 \mathrm{ft}(30 \mathrm{~m})$ are ten in number (Table 2). The thickest shale is $416 \mathrm{ft}(127 \mathrm{~m})$ and it is located at $2119-2535 \mathrm{ft}(646-773 \mathrm{~m})$. The thinnest is $96 \mathrm{ft}(29 \mathrm{~m})$ and it is located at $4088-4184 \mathrm{ft}(1246-1275 \mathrm{~m})$. These shales occur in Agbada Formation (paralic environment). Akata shales are two. They are $120 \mathrm{ft}(37 \mathrm{~m})$ and $118 \mathrm{ft}(36 \mathrm{~m})$ thick corresponding to $8057-8177 \mathrm{ft}$ (2456$2492 \mathrm{~m})$ and $8935-9053 \mathrm{ft}(2723-2759 \mathrm{~m})$ respectively. This is in conformity with Agbada and Akata Formations analyzed in Ekweozor and Daukoru, 1994.

\section{Source rock quality}

The Rock-Eval data (Table 1) indicate that the Eocene TOC varies from $2.9 \mathrm{wt} \%$ to $4.3 \mathrm{wt} \%$. This shows that the Eocene section is a good source rock. The calculated TOC, GR (TOC) from gamma ray curve shows the variation within each shale section (Table 2). The TOC decrease with depth. Agbada Formation GR (TOC) ranges from 3.7 to $4.4 \mathrm{wt} \%$, while Akata Formation GR (TOC) average are 3.8 and $3.9 \mathrm{wt} \%$. The high increase in Agbada Formation GR (TOC) is due to the presence or influence of alloctonous deposits (Bustin 1988).

In the organic-rich shale, resistivity and bulk density curves are opposite to each other. This is used to detect source rock on the logs (Meyer and Nederlof, 1984). Table 2 shows that the bulk density increases with depth. This may be due to compaction of sediments as the depth increases. For the available data, resistivity decrease with depth, except at shale number 8, located at 4224-4356ft (1287-1328m), Agbada Formation where the resistivity is $3.8 \Omega \mathrm{m}$ ).

\section{Detection of source rock and organic maturity}

Resistivity and density $\operatorname{logs}$ were used in this analysis to identify the source rock in each shale section. In the organicrich shale, resistivity and bulk density curves were opposite to each other. Sediments can be regarded as consisting of heavy and light fractions (Meyer and Nederlof, 1984). Tables' 3-7 shows variation of resistivity and bulk density within the shale sequences. This was used to analyze the source rock potentials in conjunction with the TOC contents. The TOC indicated that the organic matter is of the right quantity and it is very good (greater than 1wt\% (Tissot and Welte, 1978).

Table 3: Maturity zones 


\begin{tabular}{|l|l|l|l|l|}
\hline Zones & $\begin{array}{l}\text { Resistivity } \\
(\mathrm{av} .) \mathrm{Rm}\end{array}$ & $\begin{array}{l}\text { Bulk density } \\
\left(\mathrm{av} . \mathrm{kg} / \mathrm{m}^{3}\right.\end{array}$ & Depth (ft) & Depth (m) \\
\hline Immature & 2.33 & 2.3 & $3900-3970$ & $1889-1210$ \\
\hline Accumulation & 3.0 & 2.4 & $3970-3980$ & $1210-1213$ \\
\hline Mature & 2.7 & 2.3 & $3980-4000$ & $1213-1219$ \\
\hline
\end{tabular}

Table 4: Maturity zones

\begin{tabular}{|l|l|l|l|l|}
\hline Zones & $\begin{array}{l}\text { Resistivity } \\
\text { (av.) } \Omega m\end{array}$ & $\begin{array}{l}\text { Bulk } \\
\text { density } \\
(\text { av.)kg/m }\end{array}$ & Depth (fo) & Depth (m) \\
\hline Immature & 1.95 & 2.3 & $4109-4157$ & $1252-1267$ \\
\hline Accumulation & 2.6 & 2.3 & $4157-4159$ & $1267-1268$ \\
\hline Mature & 2.0 & 2.3 & $4159-4177$ & $1268-1273$ \\
\hline
\end{tabular}

Table 5: Maturity zones

\begin{tabular}{|l|l|l|l|l|}
\hline Zones & $\begin{array}{l}\text { Resistivity } \\
(\mathbf{a v}) \text { (9w }\end{array}$ & $\begin{array}{l}\text { Bulk density } \\
(\mathbf{a v} .) \mathrm{kg} / \mathrm{m}^{\mathbf{3}}\end{array}$ & Depth (ft) & Depth (m) \\
\hline Immature & 3.3 & 2.3 & $4224-4344$ & $1287-1324$ \\
\hline Accumulation & 10.3 & 2.42 & $4344-4347$ & $1324-1325$ \\
\hline Mature & 8.3 & 2.5 & $4347-4353$ & $1325-1328$ \\
\hline
\end{tabular}

Table 6: Maturity zones

\begin{tabular}{|l|l|l|l|l|}
\hline Source rock zone & $\begin{array}{l}\text { Resistivity av. } \\
(\Omega \mathrm{m})\end{array}$ & $\begin{array}{l}\text { Density av. } \\
\left(\mathrm{kg} / \mathrm{m}^{3}\right)\end{array}$ & Depth (f0) & Depth (m) \\
\hline Immature & 2.19 & 2.53 & $8119-8122$ & $2475-2476$ \\
\hline Accumulation & 3.85 & 2.56 & $8130-8150$ & $2478-2484$ \\
\hline Mature & 3.08 & 2.55 & $8160-8165$ & $2487-2489$ \\
\hline
\end{tabular}

Table 7: Maturity zones

\begin{tabular}{|l|l|l|l|l|}
\hline Source rock zone & $\begin{array}{l}\text { Resistivity av. } \\
(\Omega \mathrm{s})\end{array}$ & $\begin{array}{l}\text { Density } \\
\left(\mathrm{kg} / \mathrm{m}^{3}\right)\end{array}$ & Depth (fo & Depth (m) \\
\hline Immature & 1.7 & 2.46 & $8950-9000$ & $2728-2743$ \\
\hline Accumulation & 2.9 & 2.48 & $9010-9015$ & $2746-2748$ \\
\hline Mature & 2.19 & 2.51 & $9020-9040$ & $2749-2755$ \\
\hline
\end{tabular}

3805-4053ft (1060-1235m): Agbada section

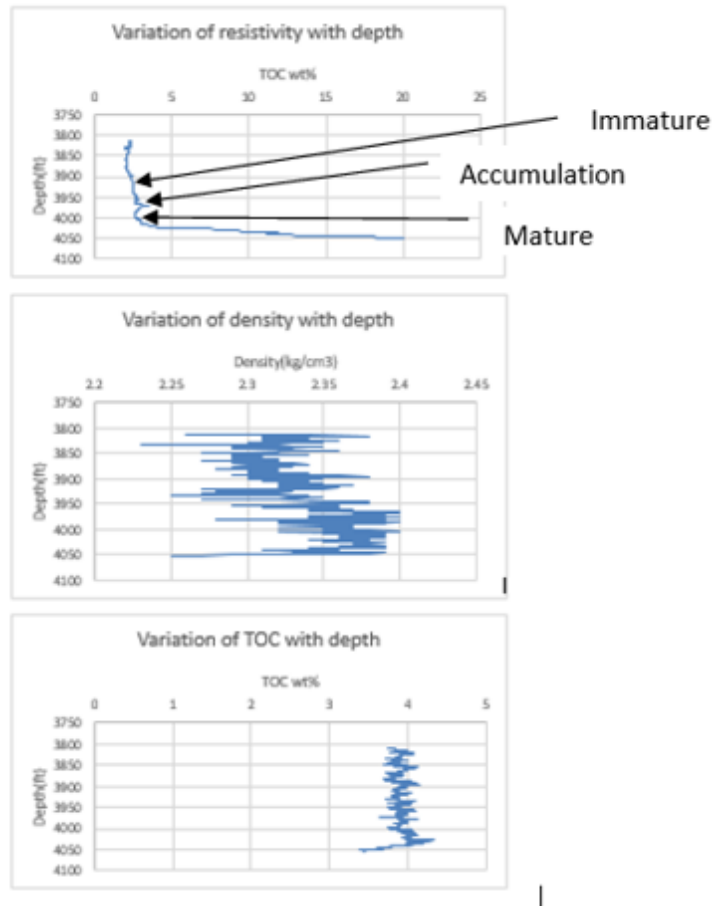

Figure 4: Resistivity, density and TOC variation with depth.

In Table 2, average resistivity and bulk density for the interval are $3.7 \Omega \mathrm{m}$ and $2.3 \mathrm{~kg} / \mathrm{m}^{3}$ respectively. The bulk density divided the shale section into two (Fig. 4). The lower section has a higher bulk density than the average, $2.3 \mathrm{~kg} / \mathrm{m}^{3}$. The resistivity gradually increase with depth. There is a very high resistivity below $4021 \mathrm{ft}$. This contradict the prediction that the organic-rich interval has lower bulk density in relation to the resistivity, Jia et al (2012). However, the resistivity zoned the section into three, accumulation zone 3970-3979ft (1149 $1213 \mathrm{~m}$ ) separates immature zone from mature zone at $3958 \mathrm{ft}$ with resistivity value of $2.9 \Omega \mathrm{m}$ average. Immature zone at the top of the accumulation zone has average resistivity value of $2.6 \Omega \mathrm{m}$, the mature zone average resistivity value is $2.7 \Omega \mathrm{m}$. The resistivity value of the mature zone lies in-between mature and accumulation zones. The accumulation zone is not too prominent.

\section{8-4184ft (1246-1275m): Agbada section}

The average resistivity and density of this interval in Table 2 are $3.4 \Omega \mathrm{m}$ and $2.3 \mathrm{~kg} / \mathrm{cm}^{3}$ respectively. Average TOC value, GR (TOC) is $3.8 \mathrm{wt} \%$. This value of TOC show a good quality source rock. At $4088-4100 \mathrm{ft}$, the resistivity average is $(3.2$ $\Omega \mathrm{m})$ and the corresponding bulk density value is $2.3 \mathrm{~kg} / \mathrm{cm}^{3}$. 


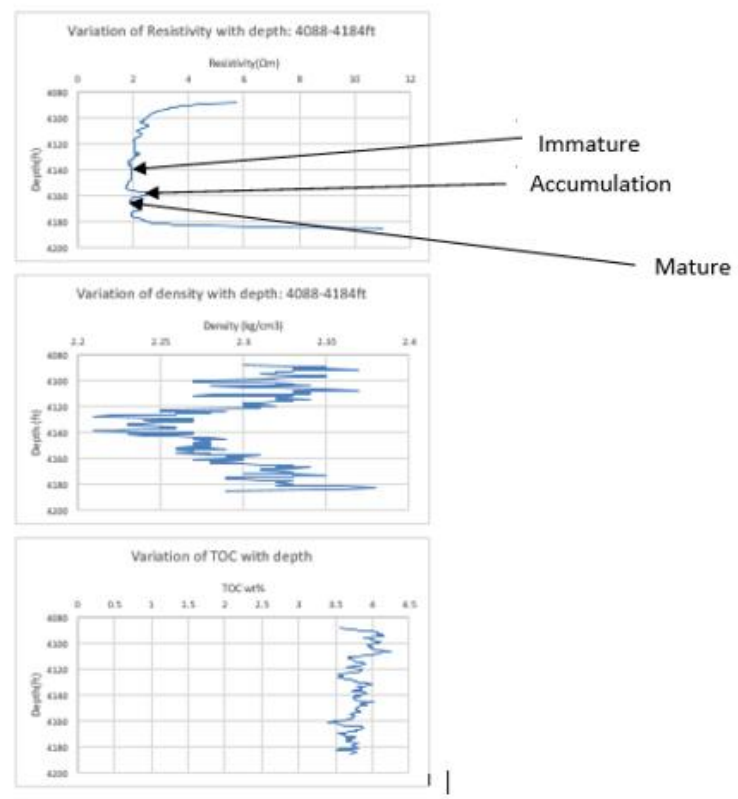

Figure 5: Resistivity, density and TOC variation with depth.

These values cannot detect the source rock potential because of the low resistivity, lower than the overall average. However the resistivity curve detected three zones of source rocks, Fig. 5 and Table 4. The onset of hydrocarbon generation is at $4157 \mathrm{ft}(1267 \mathrm{~m})$. Zone of oil accumulation has average resistivity $2.6 \Omega \mathrm{m}$. This separates an immature zone at the top (resistivity, $1.95 \Omega \mathrm{m}$ ) from lower mature zone (resistivity, $2 \Omega \mathrm{m}$ ). The accumulation zone is not very prominent.

\section{4-4356ft (1287-1328m): Agbada Section}

The average resistivity and density of this interval in Table 2 are $3.8 \Omega \mathrm{m}$ and $2.3 \mathrm{~kg} / \mathrm{cm}^{3}$ respectively. Average TOC value, GR (TOC) is $3.7 \mathrm{wt} \%$. This value of TOC show a good quality source rock._At 4224 - 4250ft (1287-1295m) in Figure 6, resistivity and the density are lower than the average. There is no source rock detected because low resistivity corresponds to low density. However, the resistivity curve separated the section into three, the upper immature zone, the middle accumulation zone and the lower mature zone, Fig. 6 and Table 5. The accumulation is not too prominent.

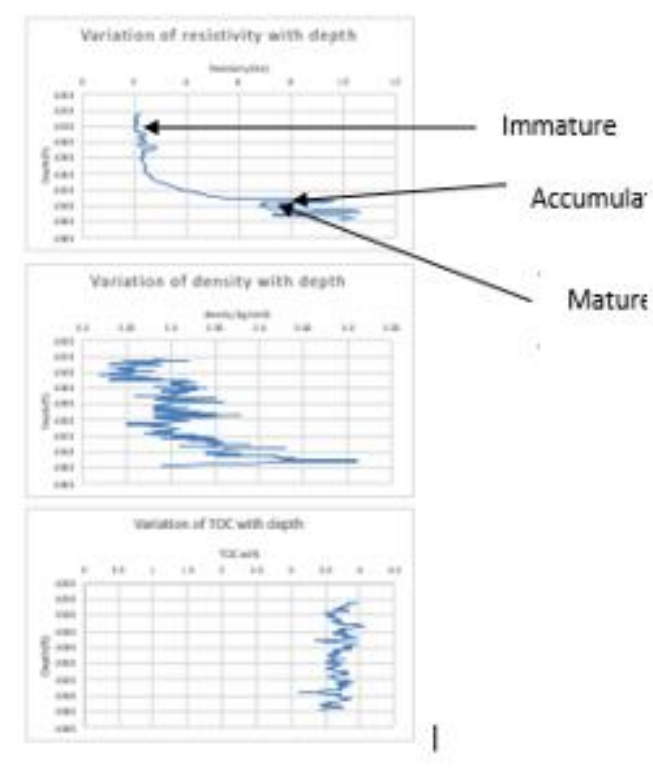

Figure 6: Resistivity, density and TOC variation with depth.

\section{7-8177ft (2456-2492m)}

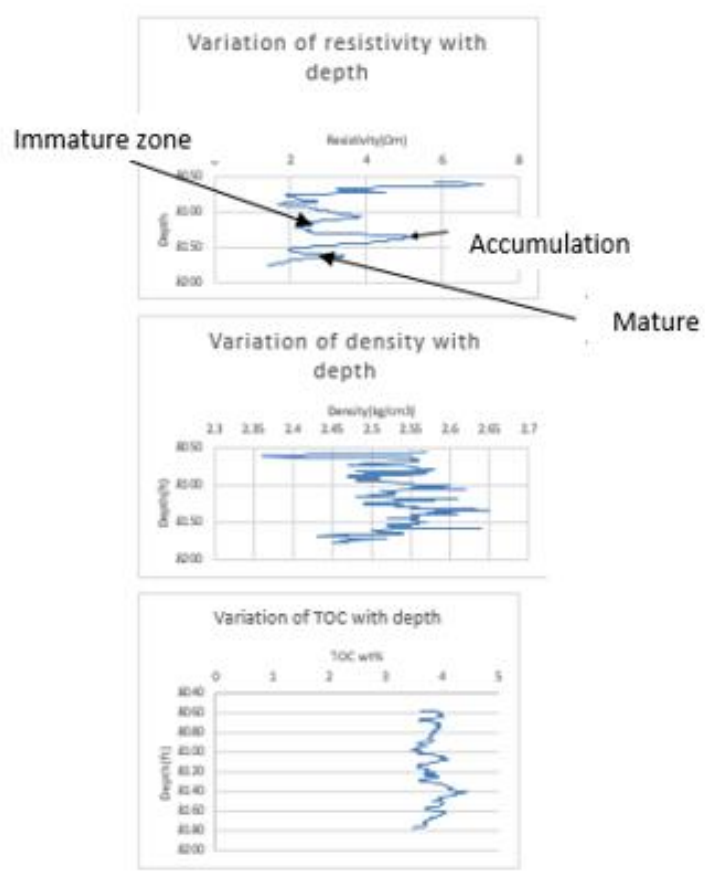

Figure 7: Resistivity, density and TOC variation with depth.

In Table 2, the average resistivity is $3 \Omega \mathrm{m}$ and the average density is $2.5 \mathrm{~kg} / \mathrm{cm} 3$. Average TOC value, GR (TOC) is $3.9 \mathrm{wt} \%$. This value of TOC show a good quality source rock. At $8057-8073 \mathrm{ft}(2457-2461 \mathrm{~m})$ in Figure 7 , the resistivity is very high (average, $4.5 \Omega \mathrm{m})$. At $8058-8064 \mathrm{ft}(2456-2458 \mathrm{~m})$, the bulk density is very low $(2.4 \mathrm{~kg} / \mathrm{cm} 3)$. Source rock 
potential is detected in this shale. The section is further divided into three in Fig. 7 and Table 6, accumulation zone is at an average depth of $8145 \mathrm{ft}(2482 \mathrm{~m})$ with average resistivity value of $5.1 \Omega \mathrm{m}$. The immature and immature zones have average resistivity of $2.2 \Omega \mathrm{m}$ and $3 \Omega \mathrm{m}$ respectively. Accumulation zone is prominent and zones are clearly separated in the figure.

\section{5-9053ft (2723-2759m): Akata section}

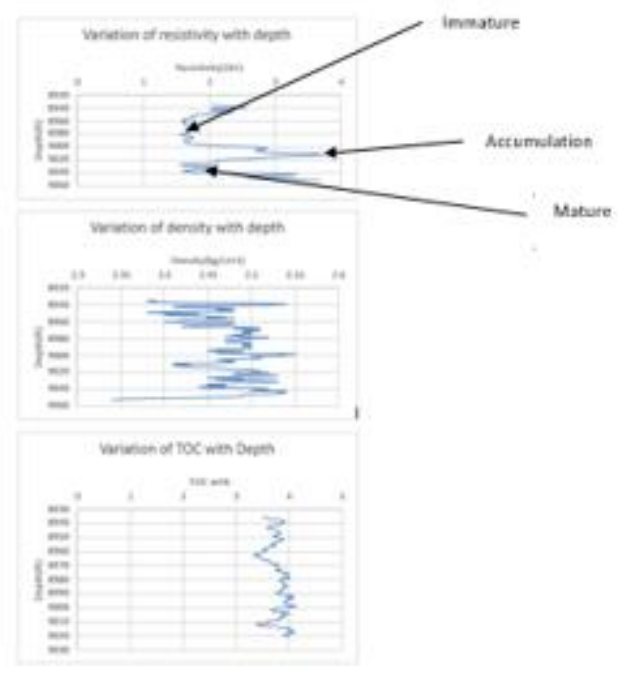

Figure 8: Resistivity, density and TOC variation with depth

In Table 2, the average resistivity of this interval is $2.2 \Omega \mathrm{m}$ and the average density is $2.5 \mathrm{~kg} / \mathrm{cm} 3$. Average TOC value, GR (TOC) is $3.8 \mathrm{wt} \%$. This value of TOC show a good quality source rock.

At $9004-9017 \mathrm{ft}(2744-2748 \mathrm{~m})$, the bulk density is very low (lower than the average), Fig. 8. It ranges from 2.41$2.49 \mathrm{~kg} / \mathrm{cm} 3$. At $8998-9020 \mathrm{ft}(2743-2749 \mathrm{~m})$, the resistivity is very high (higher than the average). It ranges from 2.25$3.72 \Omega \mathrm{m}$. The resistivity and the bulk density have opposite trend. Source rock potential is detected. In addition, the section is divided into three based on the resistivity sequence. The accumulation zone has the highest resistivity $(2.9 \Omega \mathrm{m})$ indicating hydrocarbon expulsion. The immature and mature zones have respective resistivity of $1.7 \Omega \mathrm{m}$ and $2.2 \Omega \mathrm{m}$. Accumulation zone is prominent and zones are clearly separated in the figure.

\section{CONCLUSION}

This study has established the importance of source rock studies using resistivity and density logs in investigating the hydrocarbon generation potentials of Pologbene-001 in
Northern Delta depobelt of Niger Delta Basin. Investigation of Eocene Formation indicates that shales of the Akata and Agbada Formation are good source rocks. However, the Akata Formation shows better potential than Agbada Formation.

\section{References}

[1] Benesh N. P., Plesch A. Shaw J. H. (2014) Geometry, kinematics, and displacement characteristics of tear-fault systems: An example from the deep-water Niger Delta, AAPG Bull 98: 465-482.

[2] Bilotti F. Shaw J. H., Cupich R. M., Lakings R. M. (2005) Detachment fold, Niger Delta. AAPG Studies in Geology 53: 103-104.

[3] Bouvier J D, Kaars-Sijpesteijn, CH, Kluesner DF, Onyejekwe CC, Van Der Pal RC (1989) Three-dimensional seismic interpretation and fault sealing investigations, Nun River Field, Nigeria, AAPG Bull 73: 1397-1414.

[4] Bustin R. M. (1988) Sedimentology and Characteristics of Dispersed Organic Matter in Tertiary Niger Delta, Origin of Source Rocks in a Deltaic Environment. AAPG Bull 72: 277298.

[5] Corredor F., Shaw J. H., and Bilotti F. (2005) Structural styles in the deep-water fold and thrust belts of the Niger Delta: AAPG Bull 89: 753-780

[6] Ekweozor C. M., Daukoru E. M. (1994) Northern delta depobelt portion of the Akata- Agbada. (1) Petroleum system, Niger Delta, Nigeria, In, Magom, L.B., and Dow, W.G., eds. The petroleum system- from source to Trap. AAPG Memoir 60: Tulsa, $599-614$.

[7] Ekweozor C. M., and Okoye N. V. (1980) Petroleum source-bed evaluation of Tertiary Niger Delta. AAPG Bull 64: 12511259.

[8] Evamy B. D., Haremboure J., Kamerling P., Knaap W. A., Molloy F. A., Rowlands P. H. (1978) Hydrocarbon Habitat of Tertiary Niger Delta. AAPG Bull 62: 1-39.

[9] Haack R. C., Sundararaman P., Diedjomahor J. O., Xiao H., Gant N. J., May E. D., Kelsch K. (2000). Niger Delta petroleum systems, Nigeria, in M. R. Mello and B. J. Katz, eds., Petroleum systems of South Atlantic margins. AAPG Bull 73: 213-231.

[10] Hedberg H. D. (1968) Significance of high-wax oils with respect to genesis of petroleum. AAPG Bull 52: 736-750.

[11] Hinds G. S. and R. R. Berg (1990) Estimating Organic Maturity from Well Logs, Upper Cretaceous Austin Chalk, Texas Gulf Coast: Transactions- Gulf Coast Association of Geological Societies, v. XL, p. 295-300

[12] Jia J., Liu Z., Meng Q., Liu R., Sun P., Chen Y. (2012) Quantitative evaluation of Oil Shale Based on Well Log and 3D Seismic Technique in the Songliao Basin, Northeast China: Oil Shale 29: 128-150.

[13] Meyer B. L., Nederlof, M. Y. (1984) Identification of source rock on wireline logs by density/resistivity and sonic transit time/resistivity crossplots. AAPG 68: 121-129. 
[14] Nyantakyi E. K. W., Hu S., Borkloe J. K., Nagre R. D., Frimpong I. K. (2014) Geochemical Investigation of Potential Source Rocks for Agbada Formation, Osioka South Area, Western Niger Delta, Nigeria. Geosciences 4: $13-22$

[15] Passey Q. R. S., Creaney J. B., Kulla F. J., Moretti Stroud J. D. (1990) A practical model for organic-richness from porosity and resistivity logs. AAPG 74: 1777-1794.

[16] Olisa B. A. (2016) Estimating source-rock organic richness from well data in parts of western Niger Delta, Nigeria. Ph.D thesis, Federal University of Technology, Akure, Nigeria: 198-201

[17] Olisa B. A., Ako B. D., Ojo J. S. (2018) Estimation of source rock organic-richness from gamma ray (gr) log: Eocene section, parts of the western Niger Delta. IOSR-JAGG 6 (March): 37-44

[18] Oluwajana O. A., Ehinola O. A., Okeugo C. G., Adegoke O. (2017) Modeling hydrocarbon generation potentials of Eocene source rocks in the Agbada Formation, Northern Delta Depobelt, Niger Delta Basin, Nigeria. Journal of petroleum exploration and technology 7: 379-388.

[19] Short K. C., Stauble A. J. (1967) Outline of geology of Niger Delta, AAPG Bull 51: 761-779.

[20] Tissot B. P., Welte D. H. (1978). Petroleum formation and occurrence: Berlin, Springer-Verlag: 521

[21] Weber K. J., Daukoru E. M. (1975) Petroleum geology of the Niger Delta. Proceedings of the ninth world petroleum congress, Tokyo 2: 209-221.

[22] Wu S., Bally A. W. (2000) Slope tectonics: Comparisons and contrasts of structural styles of salt and shale tectonics of the northern Gulf of Mexico with shale tectonics of offshore
Nigeria in Gulf of Guinea, in W. U. Mohriak and M. Talwani, eds., Atlantic rift and continental margins: Geophysical Monograph 115: 151-172. 